\title{
ВИКОРИСТАННЯ МЕТОДІВ МУЛЬТИМЕДІЙНИХ ТЕХНОЛОГІЙ У НАВЧАЛЬНОМУ ПРОЦЕСІ
}

\author{
Т. В. Чорненька, С. О. Коноваленко \\ Горлівський медичний коледж \\ ДвнЗ «Тернопільський державний медичний університет \\ імені І. Я. Горбачевського МОЗ Украӥни»
}

У статті висвітлено методи мультимедійних технологій, які використовують в навчальному процесі та вплив їх застосування на ефективність засвоєння знань при використанні комп’ютерної техніки.

\section{THE USAGE OF MULTIMEDIA TECHNOLOGIES METHODS IN EDUCATIONAL PROCESS}

\author{
T. V. Chornenka, S. O. Konovalenko \\ Horlivka Medical College \\ I. Horbachevsky Ternopil State Medical University
}

The article highlights different methods of multimedia technologies, used in the educational process and the impact of their usage on the effectiveness of students' knowledges.

Вступ. У системі реформування медсестринської освіти в Україні актуальним є впровадження мультимедійних технологій в навчальний процес, які дають можливість забезпечити формування високого рівня професійної компетентності майбутніх медичних фахівців.

Серед інноваційних педагогічних технологій вони мають значимість, яку важко переоцінити, оскільки вони допомагають вирішити протиріччя між зростаючою складністю навчання і збільшенням потоку інформації та індивідуальними особливостями кожного студента. Значимість мультимедійних технологій ще й в тому, що вони мають велику перспективу розвитку, адже їм властива різнонаправленість та багатогранність [2].

Основна частина. Мультимедійні технології навчання - це достатньо молоде явище, однак їм відводять значну роль в оптимізації навчально-виховного процесу. Оптимальним вважається процес навчання, що одночасно відповідає таким критеріям:

- зміст, структура та логіка функціонування процесу навчання забезпечує ефективне та якісне вирішення задач на рівні максимальних навчальних можливостей кожного студента;

() Т. В. Чорненька, С. О. Коноваленко, 2016
- поставлені цілі досягаються шляхом диференційованого підходу, суб'єктивних взаємовідносин, модернізації та вдосконалення процесу навчання.

Термін «мультимедіа» означає спектр інформаційних технологій, що використовують різні програмні й технічні засоби з метою найефективнішого впливу на користувача (що став одночасно і читачем, і слухачем, і глядачем).

Завдяки застосуванню в мультимедійних продуктах і послугах одночасної дії графічної, аудіо і візуальної інформації ці засоби володіють великим емоційним зарядом і активно включають увагу користувача, сприяють створенню міцних знань.

Експериментально установлено, що при усному викладанні матеріалу за хвилину слухач сприймає і здатний обробити до однієї тисячі умовних одиниць інформації, а при «підключенні» органів зору до 100000 таких одиниць. Тому абсолютно очевидна висока ефективність використання в навчанні мультимедійних засобів, основа яких - гармонійна інтеграція багатьох видів інформації.

Мультимедійні продукти являють собою широкі можливості для різних аспектів навчання. Одними з основних можливостей і переваг засобів мультимедіа у разі їх застосування у навчальному процесі $\epsilon$ : 
- інтерактивність;

- інформаційна насиченість ресурсу (одночасне інтегрування різних видів інформації - високоякісної звукової, графічної фото і відеоінформації;

- різноманіття форм подання інформації і типів навчальних завдань;

- впровадження навчальних середовищ, які забезпечують «занурення» тих, хто навчається, у віртуальний світ, у професійні ситуації;

- миттєвий зворотний зв'язок, широкі можливості діалогізації навчального процесу;

- армонійне поєднання ігрової й навчальної складових мультимедіа;

- активізація навчальної роботи студентів, посилення їх ролі як суб'єкта навчальної діяльності (можливість обирати послідовність вивчення матеріалу, визначення характеру і міри допомоги);

- посилення мотивації навчання.

Отже, мультимедіа, маючи особливий вплив на сфери навчання і виховання, дає змогу інтенсифікувати процес навчання, надати йому гнучкості, динамізму, посилити його прикладну спрямованість.

Мультимедійні засоби навчання займають важливе місце у розвитку інформаційного суспільства. Мультимедійні засоби навчання за С. У. Гончаренко це комплекс апаратних і програмних засобів, що дозволяють користувачеві спілкуватися з комп'ютером, використовуючи різноманітні, природні для себе середовища: графіку, гіпертексти, звук, анімацію, відео. Мультимедійні системи надають користувачеві персонального комп'ютера такі види інформації: текст, зображення, анімаційні картинки, аудіокоментарі, цифрове відео. Технології, які дозволяють за допомогою комп'ютера інтегрувати, обробляти і водночас відтворювати різноманітні типи сигналів, різні середовища, засоби і способи обміну інформацією, називаються мультимедійними [1, 3].

Мультимедійні засоби єуніверсальними, оскільки можуть бути використані на різних етапах заняття під час:

- самостійної підготовки студента;

- мотивації як постановки проблеми перед вивченням нового матеріалу;

- пояснення нового матеріалу як ілюстрації;

- закріплення знань;

- контролю вхідного та вихідного рівнів знань.

Існують різноманітні способи застосування засобів мультимедіа в навчальному процесі, а саме:

- використання електронних лекторів, тренажерів, енциклопедій, підручників;
- моделювання процесів і явищ;

- забезпечення дистанційної форми навчання;

- розробка ситуаційно-рольових та інтелектуальних ігор з використанням штучного інтелекту;

- електронні підручники;

- мультимедіа-презентації;

- навчально-демонстраційні й контролюючі програми;

- проведення інтерактивних телеконференцій;

- створення сайтів навчальних закладів;

- побудова систем контролю й перевірки знань і умінь студентів(використання контролюючихпрограмтестів);

- створення презентацій для викладання навчального матеріалу;

- здійснення проективної і дослідницької діяльності студентів.

Потрібно підкреслити, що використання засобів мультимедіа в освітньому процесі сприяє:

- мотивації студентів до навчання;

- реалізації соціальної мети, а саме - інформатизації суспільства;

- підвищенню рівня процесу навчання;

- розвитку особистості студента;

- розвитку навичок самостійної роботи з навчальним матеріалом;

- підвищенню ефективності навчання за рахунок його індивідуалізації.

Моделювання реальності - найважливіша перевага мультимедійних технологій. За їх допомогою можна не лише відтворити будь-який об'єкт, але й забезпечити його програмою, яка описує його поведінку в реальних умовах. Завдяки цій «віртуальній лабораторії» студент відпрацьовує професійні дії, які максимально відповідають реальним, насправді маючи справу лише з їх електронним аналогом. Система може містити підказки, що спрямовують дії студента, дає оцінку результатів його діяльності, а також дозволяє повторити дію певного етапу для виправлення помилок необхідну кількість разів. При цьому не створюється загроза життю чи здоров'ю пацієнта $[4,5]$.

У Горлівському медичному коледжі в навчальний процес активно впроваджуються комп'ютерні технології, які включають появу віртуальних лабораторій, що сприяють формуванню якісного медичного персоналу.

Елементи віртуальної лабораторії використовують для студентів I та II курсів з дисциплін: «Основи медсестринства», «Медсестринство в оториноларингології», «Репродуктивне здоров'я та планування сім'і». 
На практичних заняттях із даних дисциплін студентам пропонують виконання практичних навичок за допомогою комп'ютерних програм (заповнення німих граф, визначення послідовності дій, оцінювання правильності отриманого результату та ін.).

Студенти із зацікавленістю ставляться до даних завдань, проявляють творчу та розумову активність. Отже, використання елементів комп'ютерних програм дуже ефективно впливає на засвоєння студентами практичних навичок з поданих дисциплін.

Дана методика ефективна для виконання навичок, які не можливо відпрацювати у кабінетах доклінічної практики. При неправильному виконанні навички студент завжди має можливість виправити та провести роботу над помилками.

Під час проведення дослідження елементи віртуальної лабораторії використовували для 50 \% студентів I курсу та для 70 \% II курсу.

При проведенні контрольного заняття з тем, на яких використовували елементи віртуальної лабораторії, було визначено, що 30 \% засвоїли матеріал з оцінкою «5», $15 \%$ - 3 оцінкою «4» та $5 \%$ - 3 оцінкою «3» на І курсі, 55 \% - 3 оцінкою « $5 », 12 \%$ - $з$ оцінкою «4» та 3 \% - $з$ оцінкою «3» на II курсі.

Такий результат дозволяє говорити про те, що 3 впровадженням використання елементів віртуальної лабораторії ефективність засвоєння знань збільшилася на $34 \%$.

Комп'ютерні тренажери також можна використовувати для попереднього відпрацювання практичних навичок та формування вмінь, особливо з надання невідкладної допомоги в екстремальних умовах, що в реальній практиці не завжди можливо. Симуляція ситуації допомагає студентам-медикам вчитися і запам'ятовувати основні наукові концепції, формує професійні вміння, розвиває критичне мислення та дозволяє реалізуватися як творчій особистості.

Мультимедійні презентації - найбільш функціональні та ефективні засоби під час проведення лекцій, доповідей, наукових конференцій, презентацій проектів та дослідницьких робіт студентів. Використання презентацій дозволяє полегшити процес спілкування викладача і студентів під час викладання нового навчального матеріалу. Зникає необхідність багаторазового повторення визначень, термінів та прізвищ тощо. Надання матеріалуу вигляді мультимедійної презентації полегшує сприйняття інформації. Зникає необхідність перепитувати викладача, спиратись лише на своюуяву, оскільки можна побачити та детально роздивитися всі об'єкти, про які йдеться на лекції: відеофрагменти клінічних ситуацій, тематичних пацієнтів, характерних ознак захворювання, графологічні схеми, табличні та статистичні дані тощо. Це допомагає студентам краще зрозуміти новий матеріал лекції, структурувати його.

Застосування анімації підсилює сприйняття матеріалу. В багатьох випадках у медицині мультиплікація $\epsilon$ єдиним наочним представленням процесів, що відбуваються в організмі людини. Наприклад, зміни, що відбуваються в структурі крові, в головному мозку, механізм дії препарату, процес запліднення яйцеклітини та розвиток плідного яйця, схема регуляції менструального циклу тощо. Ці процеси неможливо дохідливо показати на плакаті, а тим більше на пацієнтові. Наявність якісної наочності сприяє розвитку механізмів довготривалої пам'яті.

Електронні підручники, які сьогодні все частіше використовують в процесі навчання, значно змінили наші уявлення про навчальну книгу. Вони містять не тільки текстову й графічну інформацію, а й звукові та відеофрагменти, наділені інтерактивними можливостями. Тобто, електронний підручник може надавати необхідну інформацію за запитами студентів й контролювати їх знання. Основними функціями електронного підручника як комп'ютерного педагогічного програмного засобу $є$ : навчально-пізнавальна, консультативна, контрольна. Залежно від того, наскільки студент засвоїв матеріал, можна за необхідністю повторити вивчений розділ, відкоригувати методику навчання. При низьких результатах знань можливе з'ясування думки самого студента про причини поганого засвоєння матеріалу. Електронні підручники стають не додатковими, а провідними засобами на етапах навчального процесу, звільняючи викладача від механічної роботи, надаючи йому нові можливості для творчого пошуку змісту, методів та засобів роботи із студентами [6].

Інформаційно-комп'ютерні технології в навчанні викликають все більший інтерес не тільки у потенційних студентів, а й у керівників закладів охорони здоров'я. Поряд із традиційними методами підготовки та удосконалення кадрів охорони здоров'я важливу роль відіграють і дистанційні технології. Навчальний процес з використанням сучасних комп'ютерних технологій реалізується в таких формах:

- кейс-технології;

- заочне навчання з використанням інформаційних технологій;

- інтернет-навчання;

- комбінація 1, 2 і 3 технологій. 
Що являють собою кейс-технології? До початку навчання студент отримує повний комплект (кейс) навчально-методичних матеріалів на паперових $\mathrm{i}$ електронних носіях інформації. Дисципліни вивчають послідовно, на вивчення кожної з них відводять в середньому 1 місяць, (тривалість курсу залежить від загального числа навчальних годин, встановленого освітнім стандартом). За цей період зі студентами проводять групові тьюторіали (1 або 2 рази на тиждень, у вечірній час), які відрізняються від звичайних занять. Тьюторіали - це кваліфіковані консультації по відпрацьованому студентами домашньому завданню з акцентом на вузлових моментах досліджуваної дисципліни. Після закінчення вивчення дисципліни проводять іспит або залік; традиційних сесій така форма навчання не передбачає, що виключає необхідність в тривалих навчальних відпустках [7].

Заочне навчання з використанням інформаційних технологій передбачає отримання студентами комплекту навчально-методичних матеріалів і самостійне їх вивчення відповідно до методичних рекомендацій. У цей період проводять консультації та проміжне тестування по електронній пошті. Для студентів організовують 2 сесії - літню та зимову. В період сесій проводять тьюторіали з усіх дисциплін семестру і приймають іспити.

Всю навчальну інформацію розміщують на Webсервері Навчального центру. Студенти після зарахування отримують пароль і доступ до бібліотеки Навчального центру. Консультації, проміжне та підсумкове тестування проводять по електронній пошті. Студентів, які не склали успішно хоча 6 один із тестів, до іспиту не допускають. Іспит проводять або виїзною бригадою викладачів Центру, або силами представництва. На сьогодні дистанційна медична освіта отримала широке поширення і багатоперспективні завдання телемедицини стали реальністю.

\section{ЛІТЕРАТУРА}

1. Гороль П. К. Методика використання технічних засобів навчання : навчально-методичний посібник / П. К. Гороль, Л. Л. Коношевський, М. Г. Вороліс. - К. : «Освіта України», 2007. - 256 с.

2. Губенко І. Я. Розвиток наукових досліджень в медсестринстві як основа вдосконалення медсестринської допомоги / І. Я. Губенко, Л. П. Бразалій, О. Т. Шевченко // Магістр медсестринства. - 2008. - № 1.

3. Дичківська І. М. Інноваційні педагогічні технології : навчальний посібник / І. М. Дичківська. - К., 2004.

4. Кульчицький І. Вплив сучасних комп'ютерних інформаційних технологій та традиційні методики навчання /
Використання всіх можливостей інформаційнокомп'ютерних технологій у професійній освіті та медицині дозволяє здійснити стрибок у розвитку суспільства і цивілізації, а також подолати накопичене роками відставання.

Використання мультимедіа технологій сприяє оптимізації навчального процесу та підвищенню ефективності навчальної діяльності. Вони виступають як засоби поліпшення якості каналів прямого і зворотного зв'язків у навчальному процесі, допомагають підвищити продуктивність праці викладача, процес засвоєння навчальної інформації студентами та методику корекції діяльності студентів, дозволяють реалізувати принципово нові форми та методи навчання.

Однак на шляху їх впровадження $\epsilon$ і проблеми. Насамперед це:

- необхідність забезпечення аудиторій мультимедійними проекторами, комп'ютерами та умовами використання мультимедійних технологій на заняттях;

- наявність невеликої кількості мультимедійних програм, які можуть бути безпосередньо залучені до навчальних планів;

- невисокий рівень компетентності викладачів у використанні мультимедійних технологій;

- відсутність чітких рекомендацій зі створення та впровадження мультимедійних розробок.

Висновок. Інформатизація навчального процесу передбачає поетапне, поступове впровадження в навчальний процес інформаційних технологій та засобів навчання, раціональне поєднання традиційних методів з сучасними інформаційними та мультимедійними технологіями. Зважаючи на актуальність проблеми, кожний викладач у сьогоднішніх умовах має вільно володіти не лише власним предметом, а і основними навичками залучення інноваційних технологій у процес здобуття освіти.

І. Кульчицький // Вісник Львів. ун-ту. Серія педагогічна. 2001. - Вип. 15, Ч. 2. - С. 177-185.

5. Ленінський В. В. Дидактичні вимоги до комп'ютерно орієнтованих засобів навчання / Нові технології навчання : методичний збірник/ В. В. Ленінський. - К. - 2004.

6. Ілляшенко Л. Використання мультимедійних продуктів в освітньому процесі / Л. Ілляшенко // Освіта. Технікуми, коледжі. - 2008. - № 2 (21) - С 13-21.

7. Якушкіна А. А. Віртуальні лабораторії / А. А. Якушкіна, $€$. В. Алексєєва // Питання інформатизації освіти. 2005. - № 7. 